\title{
PENGARUH PENERAPAN STRATEGI PEMBELAJARAN KONTEKSTUAL (CONTEXTUAL TEACHING AND LEARNING) TERHADAP HASIL BELAJAR SISWA PADA KELAS XI MATERI HIDROLISIS GARAM DI SMA NEGERI 1 ALALAK
}

\section{The Effect of Contextual Teaching and Learning Strategy Application Toward Students' Learning Outcome at Class XI on Salt Hydrolysis in SMA Negeri 1 Alalak}

\author{
Munawarah, Gusti Hadiatus Solehah, Okviyoandra Akhyar \\ Program Studi Pendidikan Kimia Fakultas Keguruan dan Ilmu Pendidikan \\ Universitas Islam Kalimantan Muhammad Arsyad Al Banjari, Banjarmasin \\ *e-mail: ikaagustinawulandari17@gmail.com
}

\begin{abstract}
Abstrak.Penelitian ini bertujuan mengetahui pengaruh penerapan strategi pembelajaran kontekstual (contextual teaching and learning) pada hasil belajar siswa pada materi hidrolisis garam. Penelitian ini menggunakan quasi eksperimen dengan desain penelitian pretest posttest control group design. Pada penelitian ini, kelas sampel dalam penelitian diambil menggunakan teknik porpusive sample. Jumlah sampel 2 kelas yaitu kelas XI IA2 (eksperimen) dan XI IA3 (kontrol). Peningkatan hasil belajar siswa setelah diadakan perlakuan dilihat dari data selisih nilai pretes dan postes antara kelas eksperimen dan kelas kontrol. Instrumen penelitian yang digunakan berupa tes objektif bentuk pilihan ganda. Teknik pengumpulan data dalam penelitian ini adalah berupa data kuantitatif yang diperoleh dari nilai pretest dan posttest. Pretest adalah tes hasil belajar yang bertujuan untuk mengetahui seberapa besar pengetahuan awal siswa sebelum penerapan pembelajaran kontekstual (contextual teaching and learning). Posttest adalah tes hasil belajar sesudah menggunakan pembelajaran kontekstual (contextual teaching and learning). Data awal dan data akhir dianalisis dengan menggunakan t-test. Hasil pengolahan data akhir diperoleh nilai thitung $=3,179$ dan $\mathrm{t}_{\text {tabel }}=2,013$ yang berarti $\mathrm{t}_{\text {hitung }}>\mathrm{t}_{\text {tabel }}$. $\mathrm{H}_{0}$ ditolak menunjukkan terjadinya peningkatan hasil belajar dengan peningkatan sebesar $13,10 \%$.
\end{abstract}

Kata kunci : Hasil Belajar, Strategi Contextual Teaching and Learning (CTL)

Abstract.This study aims to know the effect of contextual teaching and learning strategy application on students' learning outcome about salt hydrolysis. This research used quasy experiment with the design of pretest posttest control group design. In this study, sample class was chosen by using purposive sample technique. The total samples were 2 classes, class XI IA2 (experiment) and XI IA3 (control). Students" learning outcome improvement after the treatment was seen from the difference between pretest and posttest score between experiment and control class. Research instrument used was objective test in the form of multiple choice questions. Data collecting technique in this study was in the form of quantitative data obtained from students' pretest and posttest score. Pretest is a learning outcome test which aims to know students' initial knowledge. Posttest is a learning outcome test after using contextual teaching and learning. Preliminary and final data were analyzed by using $t$-test. The results of data processing were the value of $t_{\text {count }}=3,179$ and $t_{\text {table }}=2,013$ which meant that $t_{\text {count }}>t_{\text {table. }}$. Ho was 
rejected showing an improvement of students' learning outcome as much as 13,10

$\%$.

Keywords : Contextual Teaching and Learning Strategie, Learning outcomes

\section{PENDAHULUAN}

Tujuan dari proses pembelajaran adalah untuk meningkatkan dan mencapai suatu peningkatan hasil belajar (Gasong, 2018). Dalam proses belajar mengajar, aspek yang paling penting untuk mencapai tujuan tersebut adalah peran aktif siswa dan keterlibatan siswa terhadap materi yang disampaikan oleh guru di dalam kelas. Peran aktif siswa di dalam kelas sangat berpengaruh terhadap pencapaian tujuan pembelajaran yang diinginkan (Ramlah, Firmansyah, \& Zubair, 2014). Strategi pembelajaran yang digunakan pada saat mengajar juga berpengaruh kepada peran aktif siswa di dalam kelas (Johan, Susilo, \& Suwono, 2013). Kegiatan belajar mengajar yang bermakna ini diperlukan dalam setiap pembelajaran terutama kimia. Pada setiap materi kimia pasti ada materi yang dianggap siswa sulit dalam pembelajarannya. Hal ini tentunya akan mempengaruhi hasil belajar siswa. Hasil belajar adalah hasil dari kemampuan yang dimiliki siswa setelah mengalami suatu proses pengajaran. Dimyati dan Mudjiono (2009) menyatakan bahwa seorang siswa yang telah belajar akan memperoleh hasil belajar berupa keterampilan, pengetahuan, sikap dan nilai.

Berdasarkan observasi peneliti dengan melakukan wawancara kepada guru bidang studi kimia pada SMAN 1 ALALAK, pembelajaran dengan menggunakan cara konvensional untuk materi hidrolisis garam pada kelas XII IPA dengan rata-rata $25 \%$ siswa sudah tuntas dan $75 \%$ siswa belum tuntas mencapai KKM 75. Berdasarkan data di atas, masih terdapatnya siswa yang belum tuntas (mencapai KKM 75) pada materi pokok hidrolisis garam ini karena siswa mengalami kesulitan pemahaman konsep dan algoritmik karena kurangnya pemahaman konsep dasar siswa, sehingga membuat siswa cenderung menghafal untuk dapat menangkap hubungan antara pengalaman belajar di sekolah dengan kehidupan nyata.

Salah satu strategi pembelajaran yang dapat mengatasi persoalan tersebut adalah strategi pembelajaran Contextual Teaching and Learning. Menurut Sabil (2011), pembelajaran Contextual Teaching and Learning adalah suatu strategi pembelajaran yang menekankan kepada proses keterlibatan siswa secara penuh untuk dapat menemukan materi yang dipelajari dan menghubungkannya dengan situasi untuk dapat menerapkannya dalam kehidupan mereka. Siswa akan terlibat aktif dalam menemukan dan mengembangkan pengetahuan dalam pikirannya (Sanjaya, 2011). Pembelajaran kontekstual adalah konsep belajar yang membantu guru mengaitkan antara materi dan mendorong siswa membuat hubungan antara pengetahuan yang dimilikinya dengan penerapannya dalam kehidupan mereka sehari-hari dengan melibatkan ketujuh komponen utama pembelajaran efektif yaitu kontruktivisme, bertanya, menemukan, masyarakat belajar, permodelan, dan penilaian sebenarnya atau authentic assessment (Nurhadi, Yasin, \& Senduk, 2003). Dari permasalahan tersebut, peneliti berminat menerapkan strategi pembelajaran Contextual Teaching and Learning (CTL) yang mengaitkan pembelajaran dengan lingkungan disekitarnya, sehingga siswa mengalami sendiri masalah-masalah yang mereka hadapi dengan harapan siswa akan lebih paham 
dengan materi yang diajarkan dan materi tersebut akan bertahan lama dalam pikiran siswa.

Berdasarkan uraian tersebut, peneliti tertarik untuk melakukan suatu penelitian dalam pengajaran kimia untuk mendukung pencapaian kompetensi yang diinginkan. Penelitian ini berjudul "Pengaruh Penerapan Strategi Pembelajaran Kontekstual (Contextual Teaching And Learning) Terhadap Hasil Belajar Siswa pada Materi Hidrolisis Garam". Penelitian ini bertujuan untuk mengetahui pengaruh penerapan strategi pembelajaran kontekstual (contextual teaching and learning) pada hasil belajar siswa pada materi hidrolisis garam.

\section{METODE PENELITIAN}

\section{Jenis dan Rancangan Penelitian}

Penelitian ini merupakan kuasi eksperimen dengan rancangan penelitian yang digunakan adalah Pretest-Posttest Control Group Design (Sukardi, 2015). Sampel yang digunakan pada penelitian ini yaitu purposive sampling atau sampel yang disengaja (Sugiyono, 2015), yaitu kelas XI IA2 berjumlah 25 orang sebagai kelas eksperimen dan XI IA3 berjumlah 25 orang sebagai kelas kontrol. Desain penelitian ini terdapat dua kelas yaitu kelas kontrol dan kelas eksperimen. Bentuk dari desain Pretest - Posttest Control Group Design sebagai berikut:

Tabel 1. Pretest - Posttest Control Group Design

\begin{tabular}{llll}
\hline Kelompok & Pretest & Perlakuan & Posttest \\
\hline Eksperimen & $\mathrm{Y}_{1}$ & $\mathrm{X}$ & $\mathrm{Y}_{2}$ \\
Control & $\mathrm{Y}_{1}$ & - & $\mathrm{Y}_{2}$ \\
\hline
\end{tabular}

$\mathrm{X}_{1}$ : Perlakuan dengan Penerapan Strategi Pembelajaran kontekstual (CTL)

- $\quad$ : Perlakuan dengan tanpa Penerapan Strategi Pembelajaran kontekstual (CTL)

$\mathrm{Y}_{1}:$ Pemberian pretest

$\mathrm{Y}_{2}$ : Pemberian posttest

\section{Variabel Penelitian}

Variabel yang digunakan dalam penelitian ini terdiri dari dua jenis yaitu, variabel bebas (independent) dan variabel terikat (dependent) (Sugiyono, 2009) Variabel bebas adalah variabel yang dipilih untuk dicari pengaruhnya terhadap variabel tergantung, sedangkan variabel terikat adalah variabel yang kehadirannya dipengaruhi oleh variabel lain. Penelitian ini dapat disimpulkan bahwa terdapat dua variabel yaitu:

1.Variabel bebas (independent) adalah strategi contextual teaching and learning 2.Variabel terikat (dependent) adalah hasil belajar siswa kelas XI.

\section{Uji Prasyarat Instrumen}

Suatu instrumen tes dapat dikatakan baik jika memiliki beberapa persyaratan yaitu validitas, reliabilitas, daya pembeda dan tingkat kesukaran. Menurut Sudijono (2009), untuk uji instrumen tes yang berupa soal obyektif validitas, reliabilitas, daya pembeda dan tingkat kesukaran digunakan rumus-rumus sebagai berikut :

(1) Uji Validitas

Suatu tes dapat dikatakan mempunyai validitas tinggi apabila tes tersebut menjalankan fungsi ukurnya atau memberikan hasil ukur yang tepat dan akurat sesuai 
dengan maksud tes tersebut. Untuk mengukur validitas tes obyektif digunakan rumus korelasi Product Momen yaitu sebagai berikut :

$$
r_{x y}=\frac{n \times \sum x y-\left(\sum x\right)\left(\sum y\right)}{\sqrt{\left[n \times \sum x^{2}-\left(\sum x\right)^{2}\right]\left[n \times \sum y^{2}-\left(\sum y\right)^{2}\right]}}
$$

Keterangan :

$r_{x y}=$ Korelasi Product Momen

$\mathrm{xy}=$ Jumlah hasil kali $\mathrm{x}$ dan $\mathrm{y}$

Uji Validitas Instrumen dilakukan dengan membandingkan hasil perhitungan dengan $\mathrm{r}$ Tabel pada taraf signifikansi 5\% dengan ketentuan bahwa jika $\mathrm{r}$ hitung sama atau lebih besar dari $r$ tabel maka soal dinyatakan valid.

(2) Uji Reliabilitas

Reliabilitas menunjukkan suatu instrumen cukup dapat dipercaya untuk digunakan sebagai alat pengumpul data karena instrumen tersebut sudah baik (Arikunto, 2009). Pada penelitian ini, untuk mencari reliabilitas instrumen bentuk pilihan ganda menggunakan rumus Kuder-Richardson (K-R 20):

$$
\mathrm{r} 11=\left(\frac{n}{n-1}\right)\left(\frac{S t^{2}-\Sigma \mathrm{pq}}{s t^{2}}\right.
$$

Keterangan:

r11 = Reliabilitas instrumen

$\mathrm{n} \quad=$ Banyaknya butir soal

$\mathrm{p}=$ Proporsi subjek yang menjawab item dengan benar

$\mathrm{q} \quad=$ proporsi subjek yang menjawab item dengan salah $(\mathrm{q}=1-\mathrm{p})$

$\sum \mathrm{pq}=$ Jumlah hasil perkalian $\mathrm{p}$ dan $\mathrm{q}$

$\mathrm{St}^{2}=$ varians skor total tes

Kemudian hasil $r 11$ dibandingkan dengan $r_{\text {tabel }}$ dengan $\alpha=5 \%$, jika $r 11>r_{\text {tabel }}$ maka instrumen reliabel. Berdasarkan hasil perhitungan reliabilitas instrumen dalam penelitian ini menggunakan rumus KR-20.

Taraf Kesukaran Soal

Untuk menguji tingkat kesukaran butir soal digunakan rumus :

Keterangan:

$$
P=\frac{B}{J s}
$$

$\mathrm{P} \quad=$ Indeks kesukaran

$\mathrm{B}=$ Jumlah siswa yang menjawab soal dengan benar

Js = Jumlah seluruh siswa peserta tes

$\mathrm{P}<0,25$ soal terlalu sukar

$\mathrm{P}=0,25-0,75$ soal sedang/ cukup

$\mathrm{P}>0,75$ soal terlalu mudah

(4) Daya Pembeda

Untuk uji daya pembeda soal digunakan rumus : 
Keterangan :

$$
D=\frac{B A}{J A}-\frac{B B}{J B}=P A-P B
$$

$\mathrm{BA}=$ Banyaknya peserta kelas atas yang menjawab soal benar

$\mathrm{BB}=$ Banyaknya peserta kelas bawah yang menjawab soal benar

$\mathrm{JA}=$ Banyaknya peserta kelas atas

$\mathrm{JB}=$ Banyaknya peserta kelas bawah

PA = Proporsi peserta kelas atas yang menjawab benar

$\mathrm{PB}=$ Proporsi peserta kelas bawah yang menjawab benar

Klasifikasi Daya Pembeda:

$0,00<\mathrm{DP}<0,20=$ kurang

$0,20<\mathrm{DP}>0,40=$ cukup $/$ sedang

$0,40<\mathrm{DP}>0,70=$ Baik

$0,70<\mathrm{DP}>1,00=$ Baik sekali

\section{Teknik Analisis Data}

Sebelum melakukan uji hipotesis terlebih dahulu dilakukan uji prasyarat yairu homogenitas dan normalitas. Pengujian hipotesis hasil posttest bertujuan untuk mengetahui apakah terdapat pengaruh yang signifikan antara skor posttest kelas eksperimen dan kelas kontrol. Pengujian hipotesis menggunakan uji $\mathrm{t}$, dimana jika $\mathrm{t}_{\text {hitung }}$ $>\mathrm{t}_{\text {tabel }}$ maka Ho ditolak dan Ha diterima. Untuk pengujian tersebut diajukan hipotesis berikut :

Ho : $\mathrm{X}=\mathrm{Y}$, Tidak ada pengaruh yang signifikan antara rata-rata skor posttest kelompok ekperimen dengan kelompok kontrol.

Ha : $\mathrm{X} \neq \mathrm{Y}$, Terdapat pengaruh yang signifikan antara rata-rata skor posttest kelompok eksperimen dengan kelompok kontrol.

\section{Teknik Pengumpulan Data}

Data dalam penelitian ini adalah berupa data kuantitatif yang diperoleh dari hasil belajar siswa yaitu nilai pretest dan posttest. Pretest adalah tes hasil belajar yang bertujuan untuk mengetahui seberapa besar pengetahuan awal siswa sebelum penerapan pembelajaran kontekstual (Contextual Teaching and Learning). Posttest adalah tes hasil belajar sesudah menggunakan pembelajaran kontekstual (Contextual Teaching and Learning).

Teknik analisis data melalui data hasil pretest dan posttest kemudian dilanjutkan dengan analisis data untuk mengetahui adanya perbedaan peningkatan perolehan nilai yang di peroleh peserta didik. Besarnya peningkatan sebelum dan sesudah pembelajaran dihitung menggunakan rumus Gain Ternormalisasi.

$$
N-\text { gain }=\frac{\text { skor posttest-skor pretest }}{\text { skormaksimum-skor pretest }}
$$


Dalton : Jurnal Pendidikan Kimia dan Ilmu Kimia, Volume 1 Nomor 2, November 2018

Kriteria perolehan skor N-Gain dapat dilihat pada tabel berikut :

Tabel 2. Kategori Skor N-gain

\begin{tabular}{cc}
\hline Kategori Perolehan Skor N-Gain Batasan & Kriteria \\
\hline $\mathrm{g}>0,7$ & Tinggi \\
$0,3<\mathrm{g} \leq 0,7$ & Sedang \\
$\mathrm{g} \leq 0,3$ & Rendah \\
\hline
\end{tabular}

\section{HASIL DAN PEMBAHASAN}

Uji Validitas Instrumen dilakukan dengan membandingkan hasil perhitungan dengan $r$ Tabel pada taraf signifikansi 5\%, yaitu 0,444 dengan ketentuan bahwa jika $\mathrm{r}$ hitung sama atau lebih besar dari $r$ tabel maka soal dinyatakan valid.

Tabel 3. Hasil Uji Validitas Butir soal

$\begin{array}{ll}\text { Butir Soal } & \text { Keterangan } \\ \begin{array}{l}4,6,15,19,26,8,13,14,22,25,27,7,9,10, \\ 29,11\end{array} & \text { Valid } \\ 1,2,3,5,12,16,17,18,20,21,23,24,28,30 & \text { Tidak Valid }\end{array}$

Berdasarkan Perhitungan Koefisien indeks butir soal diperoleh hasil pada tabel berikut:

Tabel 4. Hasil Hitung Kesukaran Soal

\begin{tabular}{cc}
\hline Kategori & Butir Soal \\
\hline Terlalu Sukar & - \\
Sukar & - \\
Sedang & $4,8,9,10,11,13,14,15,25,26$, \\
Mudah & $6,7,19,22,27,29$ \\
Terlalu Mudah & - \\
\hline
\end{tabular}

Berdasarkan tabel di atas, 10 soal adalah sedang, 6 soal adalah mudah, indeks tingkat kesukaran dari 16 soal pilihan ganda adalah sedang. Hasil tersebut menunjukan bahwa instrumen soal cukup baik untuk digunakan. Soal pilihan ganda yang valid kemudian dianalisis daya pembedanya untuk mengetahui daya pembeda soal yang diklasifikasikan berdasarkan klasifikasi daya pembeda.

Hasil analisis daya beda butir soal pilihan ganda dapat di lihat pada tabel berikut ini:

Tabel 5. Hasil Hitung daya Pembeda

\begin{tabular}{cc}
\hline Kategori & Butir Soal \\
\hline Jelek & 11 \\
Cukup & $7,9,10,29$ \\
Baik & $8,13,14,22,25,27$ \\
Sangat Baik & $4,6,15,19,26$ \\
Dibuang & - \\
\hline
\end{tabular}

Uji homogenitas pretest untuk kelas eksperimen dan kelas kontrol adalah 17,14 dan 14,91, dan untuk posttest adalah 7,95 dan 13,78. Adapun F hitung untuk hasil pretest 
adalah 1,14 dengan $\mathrm{F}$ tabel 1,98 berarti $\mathrm{F}$ hitung $<\mathrm{F}$ tabel; dengan demikian, Ho diterima dan Ha ditolak. Sedangkan untuk $F$ hitung hasil posttest adalah 1,73 dengan $F$ tabel 1,98 berarti F hitung < F tabel. Dengan demikian, Ho diterima dan Ha ditolak. Dari hasil yang diperoleh dari kedua sampel kelas eksperimen dan kelas kontrol dapat disimpulkan bahwa data tersebut bersifat homogen.

Berdasarkan hasil perhitungan pretest menggunakan uji liliefors kelas kontrol dan eksperimen diperoleh hasil pretest $\mathrm{L}_{\mathrm{o}}$ sebesar 0,148 dan 0,145 . Hasil perhitungan terhadap skor tes awal belajar kelas kontrol dan eksperimen dengan $\alpha=0,05$ dan $n=25$, didapatkan harga $\mathrm{L}_{\text {tabel }}=0.173$. Hasil ini menunjukkan bahwa $\mathrm{L}_{\mathrm{o}}<\mathrm{L}_{\text {tabel, }}$, ini berarti hasil pretest kelas kontrol dan eksperimen berdistribusi normal. Sedangkan hasil perhitungan posttest menggunakan uji liliefors kelas kontrol dan eksperimen, diperoleh hasil posttest $\mathrm{L}_{\mathrm{o}}$ sebesar 0,154 dan 0,156. Pada tabel hasil perhitungan terhadap skor tes akhir belajar kelas kontrol dan eksperimen dengan $\alpha=0,05$ dan $\mathrm{n}=25$, didapatkan harga $\mathrm{L}_{\text {tabel }}=$ 0.173. Hasil ini menunjukkan bahwa $\mathrm{L}_{\mathrm{o}}<\mathrm{L}_{\text {tabel, }}$, ini berarati hasil posttest kelas kontrol dan eksperimen berdistribusi normal.

Hasil yang diperoleh untuk pretest dan posttest kelas eksperimen dan kontrol adalah rata-rata pretest kelas eksperimen yang diperoleh sebesar 42.88 dan kelas kontrol sebesar 42.12 dimana nilai tersebut hampir setara. Sedangkan untuk nilai posttest kelas eksperimen lebih besar daripada hasil rata-rata posttest kelas kontrol, yaitu rata-rata kelas eksperimen adalah 86,68, sedangkan rata-rata yang diperoleh untuk kelas kontrol adalah 78,64. Dari hasil yang diperoleh dapat dilihat bahwa rata-rata hasil posttest untuk kelas eksperimen lebih besar dibandingkan hasil pretest, begitu juga untuk kelas kontrol rata-rata posttest lebih besar dibandingkan pretest. Maka dapat disimpulkan bahwa setelah diberikan pembelajaran terdapat peningkatan hasil belajar yang diperoleh. Hasil data rata-rata pretest dan posttest yang didapatkan pada kelas eksperimen maupun kelas kontrol dilihat pada diagram batang berikut ini :

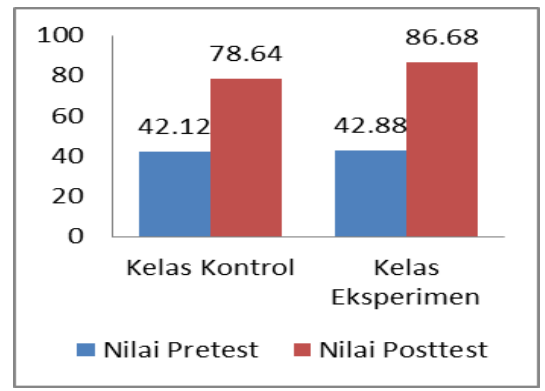

Gambar 1. Diagram Batang Skor Rata-Rata Pretest Dan Posttest

Perhitungan N-gain diperoleh dari skor pretest dan posttest masing-masing kelas eksperimen dan kelas kontrol. Peningkatan kompetensi yang terjadi sebelum dan sesudah pembelajaran dihitung dengan rumus (N-gain). Adapun untuk hasil uji $\mathrm{N}$-Gain dapat di lihat pada diagram batang berikut ini : 


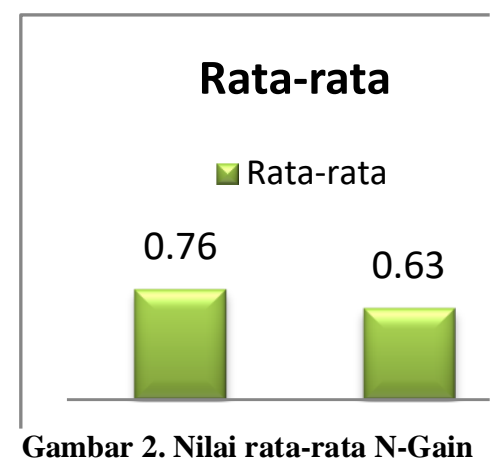

Nilai rata-rata $\mathrm{N}$-Gain kelas eksperimen adalah sebesar 0,76 dan kelas kontrol adalah 0,63. Hal ini menunjukkan bahwa peningkatan hasil belajar pada eksperimen lebih besar, yang berarti hasil belajar yang diperoleh siswa setelah diberi perlakuan dengan menggunakan strategi pembelajaran kontekstual (CTL) mengalami peningkatan. Dengan demikian, penelitian yang dilaksanakan di kelas XI IA2 di SMAN ALALAK sebagai kelas eksperimen, telah sesuai dengan hipotesis penelitan yang menyebutkan bahwa "Terdapat pengaruh terhadap hasil belajar siswa pada materi hidrolisis garam dengan menerapkan strategi pembelajaran kontekstual (Contextual Teaching and Learning)".

Selain itu, hasil perhitungan uji $\mathrm{t}$ diperoleh angka bahwa $\mathrm{t}_{\text {hitung }}=3,179$ dan dengan merujuk pada $t_{\text {tabel }}$ dengan taraf signifikasi $5 \%$ dengan $\alpha=0.05$ dan $\mathrm{df}=48$ diperoleh $t_{\text {tabel }}$ sebesar 2,013. Apabila dibandingkan $t_{\text {hitung }}$ dengan $t_{\text {tabel }}$, maka $t_{\text {hitung }}>t_{\text {tabel }}$ sehingga Ha diterima dan Ho ditolak. Maka dari itu, dapat disimpulkan bahwa ada pengaruh penerapan strategi pembelajaraan Contextual Teaching and Learning (CTL) terhadap hasil belajar siswa kelas XI IPA pada pokok bahasan hidrolisis garam di SMA Negeri 1 Alalak. Hal ini sesuai dengan pernyataan Wening dan Estidarsani (2013) yang mengungkapkan bahwa penerapan strategi CTL mampu meningkatkan hasil belajar siswa. Untuk mengetahui seberapa besar pengaruh penerapan strategi pembelajaran Contextual Teaching and Learning (CTL) terhadap hasil belajar siswa adalah melalui perhitungan berikut ini :

$$
\begin{aligned}
Y 1 & =\frac{\overline{x 1}-\overline{x 2}}{\overline{x 2}} \times 100 \% \\
Y 1 & =\frac{86,68-76,64}{76,64} \times 100 \% \\
Y 1 & =\frac{10,04}{76,64} \times 100 \%=0,131 \times 100 \%=13,10 \%
\end{aligned}
$$

Berdasarkan perhitungan diatas maka dapat disimpulkan bahwa besarnya pengaruh penerapan strategi pembelajaran Contextual Teaching and Learning (CTL) terhadap hasil belajar siswa kelas XI IPA pada pokok bahasan materi hidrolisis garam di SMA Negeri 1 Alalak adalah 13,10\%. 


\section{PENUTUP}

Berdasarkan hasil penelitian dan analisis data, dapat disimpulkan bahwa terdapat pengaruh penerapan strategi pembelajaran kontekstual (CTL) terhadap hasil belajar siswa pada materi hidrolisis garam. Hal ini dapat dilihat dari rata-rata hasil posttest kelas eksperimen lebih besar daripada hasil rata-rata posttest kelas kontrol.

Berikut saran yang dapat dijadikan sebagai masukan untuk pembelajaran lebih lanjut menggunakan strategi pembelajaran Contextual Teaching and Learning (CTL):

1. Penerapan pembelajaran Contextual Teaching and Learning (CTL) dapat dijadikan sebagai salah satu alternatif metode pembelajaran pada mata pelajaran kimia dalam upaya peningkatan hasil belajar siswa.

2. Berdasarkan kendala yang ada, sebaiknya diterapkan pada kelas yang jumlah siswanya sedikit, sehingga mereka bisa melakukan kerja kelompok dengan tenang dan lancar serta guru mudah mengawasi semua kelompok.

\section{DAFTAR RUJUKAN}

Arikunto, S. (2009). Dasar-Dasar Evaluasi Pendidikan. Jakarta: PT Bumi Aksara.

Dimyati, \& Mudjiono. (2009). Belajar dan Pembelajaran. Jakarta: PT Rineka Cipta.

Gasong, D. (2018). Belajar dan Pembelajaran. Yogyakarta: Deepublish.

Johan, A., Susilo, H., \& Suwono, H. (2013). Pengaruh Penerapan Strategi Pembelajaran Kooperatif "Plasma Cluster" Terhadap Motivasi, Keaktifan, dan Hasil Belajar Biologi Peserta Didik Kelas XI IPA SMAN 1 Ponorogo. Malang: Universitas Malang.

Nurhadi, Yasin, \& Senduk. (2003). Pembelajaran Kontekstual dan Penerapannya dalam KBK. Malang: Universitas Negeri Malang.

Ramlah, Firmansyah, D., \& Zubair, H. (2014). Pengaruh Gaya Belajar dan Keaktifan Siswa Terhadap Prestasi Belajar Matematika (Survey pada SMP Negeri di Kecamatan Klari Kabupaten Karawang). Jurnal Ilmiah Solusi, 1(3), 68-75.

Sabil, H. (2011). Penerapan Pembelajaran Contextual Teaching \& Learning (CTL) Pada Materi Ruang Dimensi Tiga Menggunakan Model Pembelajaran Berdasarkan Masalah (MPBM) Mahasiswa Program Studi Pendidikan Matematika FKIP UNJA. EDUMATICA, 1(1), 4456.

Sanjaya, W. (2011). Strategi Pembelajaran Berorientasi Standar Proses Pendidikan. Jakarta: Kencana.

Sudijono, A. (2009). Pengantar Statistik Pendidikan. Jakarta: Rajawali Pers.

Sugiyono. (2015). Statistika Untuk Penelitian. Bandung: Alfabeta.

Sukardi. (2015). Metodologi Penelitian Pendidikan Kompetensi dan Praktiknya. Jakarta: PT Bumi Aksara.

Wening, T., \& Estidarsani, N. (2013). Penerapan Contextual Teaching and Learning (CTL) Pada Mata Diklat Teknik Gambar Bangunan Sebagai Upaya Peningkatan Hasil Belajar Siswa Kelas XI SMK Negeri 1 Kemlagi Mojokerto. Jurnal Kajian Pendidikan Teknik Bangunan, $1-11$. 